Stephanie J. Lawson

Assistant Professor of Marketing College of Business Administration

Winthrop University

209 Thurmond Building

Rock Hill, SC 29733

P: (804) 310-7867 F: (803) 323-3960

stephaniejlawson@gmail.com

Mark R. Gleim*

Assistant Professor of Marketing

College of Business and Innovation

The University of Toledo

Mail Stop \#103

Toledo, OH 43606

P: (419) 530-2199 F: (419) 530-4610

mark.gleim@utoledo.edu

Rebeca Perren

Assistant Professor of Marketing

College of Business Administration

California State University San Marcos

333 S. Twin Oaks Valley Rd.

San Marcos, CA 92096

P: (760) 750-8568

rperren@csusm.edu

Jiyoung Hwang

Assistant Professor of Marketing

Bryan School of Business and Economics

University of North Carolina at Greensboro

Greensboro, NC 27402

P: (336) 334-4472 F: (336) 334-5580

j_hwang3@uncg.edu 


\title{
Freedom From Ownership: An Exploration of Access-Based Consumption
}

\begin{abstract}
Consumers are increasingly attracted to the idea of accessing products instead of owning them. This shift is important to businesses as they pursue the growing market of consumers engaging in alternative forms of consumption. Access-based business models align consumer self-interest with responsible consumption behaviors, enabling consumers, businesses and society to benefit through this unique form of exchange. A multi-method approach examines the perceived motivations that impact consumers' willingness to access products through socially networked short-term rentals. The results suggest that multiple factors drive consumer attitudes. A cluster analysis reveals four distinct groups of consumers with varying dispositions towards access- based consumption: Fickle Floaters, Premium Keepers, Conscious Materialists and Change Seekers. This research provides an actionable segmentation framework for business practice.
\end{abstract}

Key Words: Access-Based Consumption; Cluster Analysis; Mixed Methods; Segmentation 


\section{Introduction}

Ownership, or rather the lack thereof, is one of the pivotal changes occurring in today's business environment. A growing number of consumers are engaging in alternatives to ownership, often referred to as access-based consumption, where consumers gain access to the products they seek, but no transfer of ownership takes place (Bardhi \& Eckhardt, 2012). In this type of exchange, consumers pay for the experience of temporarily using the products through rental and/or membership fees. Car and bike sharing services (e.g., ZipCar, B-Cycle), luxury product rentals (e.g., Rent the Runway, The Mr. Collection) and intangibles, like skills (e.g., TaskRabbit) or available space (e.g., AirBnB), are just a few examples of this growing form of socially networked short-term access. A recent PwC study estimates access-based consumption revenues rising from $\$ 15$ billion globally in 2014 to over $\$ 300$ billion by 2025 (Zhuo, 2015). This research explores consumer motivations for accessing products and equips firms seeking to tap into this growing marketplace with an actionable framework for effective market segmentation.

Access-based consumption is available across many categories, including but not limited to clothing, tools, cars, handbags, golf clubs, bicycles and accommodations. Academic research is only beginning to investigate this form of marketplace exchange, despite increased recognition of the access-based consumption phenomenon (Bardhi \& Eckhardt, 2012; Belk, 2014; Lamberton \& Rose, 2012; Moeller \& Wittkowski, 2010; Ozanne \& Ballantine, 2010; Schaefers, Lawson, \& Kukar-Kinney, 2015). As consumers shift away from traditional forms of ownership, forward-looking firms that regard changing technologies and environmental trends as opportunities rather than threats can benefit by being on the forefront of delivering disruptive technologies (Belk, 2014). In order to do so, it is important for firms to understand what motivates consumers to participate in access-based consumption. 


\section{Defining the Scope of Access-based Consumption}

Access-based consumption is defined as "market-mediated transactions that provide customers with temporarily limited access to goods in return for an access fee, while the legal ownership remains with the service provider" (Schaefers, et al., 2015, p. 3). Access-based business models differ from traditional renting in that these market-mediated exchanges take place among consumers using intermediary firms leveraging the use of networked technologies on a scale never before possible (Botsman \& Rogers, 2010). For example, Zipcar, a car sharing service that allows consumers to rent vehicles by the hour, uses smart phone technology to allow users to book and access the vehicles on location. Moreover, these access-based business models rely on consumers to be active participants in the service provision. Access-based firms can be environmentally advantageous because a product that would have previously been owned by an individual and used infrequently is instead shared among multiple consumers maximizing usage (Botsman \& Rogers, 2010).

Access-based business models are of particular interest to firms as these economic exchanges rely on market-mediation and are underscored by profit motives (Bardhi \& Eckhardt, 2012). Understanding consumer motivations to engage in access-based consumption is critical to providing a successful business platform, yet the motivating factors for adoption of these business models are not well known. We undertake this research problem with a mixed method approach. Next, consumer motivations to engage in access-based consumption are explored with a qualitative study, followed by a larger-scale quantitative study that enables the creation of a segmentation framework that firms can put into practice. 


\section{Study 1: Exploration of Perceived Consumer Motivations}

\subsection{Sample and Data Collection}

This study utilizes an open-ended survey where participants were asked to recall instances where they may have engaged in access-based consumption. The survey was sent to 400 U.S.-based consumers that participated in a large public university panel; the data collection resulted in a sample of 72 individuals (18\% response rate). The panel was open to any person over the age of 18 , and is quite representative of an average consumer, as evidenced by the demographic information of the sample (see Table 1). The goal was to gather information from a diverse set of individuals that may, or may not, engage in various access-based consumption activities. This type of qualitative analysis is used to uncover emergent patterns or themes by categorizing incidents or stories (Reynolds, Folse, \& Jones, 2006; Spiggle, 1994). Rather than being generalizable, this analysis technique allows us to provide insight into the nature of a phenomenon and is integrated with the theory utilized in the next study (Meuter, Ostrom, Roundtree, \& Bitner, 2000; Spiggle, 1994).

This open-ended exploration started by defining and describing access-based consumption. Participants were then asked to recall instances they had engaged in access-based consumption and list items that they recently rented, borrowed, or shared with others.

Specifically, participants were asked to list six items, or instances, when they accessed products and to describe the item or example. Then, participants were asked to explain their rationale for engaging in these behaviors and to further elaborate on what they perceived as the benefits, or negative aspects, of it. 
Table 1

Participant Demographics

\begin{tabular}{|c|c|c|}
\hline Demographics & Study 1 & Study 2 \\
\hline \multicolumn{3}{|l|}{ Age Range } \\
\hline $18-35$ & $48.6 \%$ & $59.8 \%$ \\
\hline $36-54$ & $41.7 \%$ & $28.5 \%$ \\
\hline $55+$ & $9.7 \%$ & $11.7 \%$ \\
\hline Mean Age & 35.7 & 36.5 \\
\hline \multicolumn{3}{|c|}{ Sex } \\
\hline Male & $50.0 \%$ & $58.9 \%$ \\
\hline Female & $50.0 \%$ & $41.1 \%$ \\
\hline \multicolumn{3}{|l|}{ Education } \\
\hline High School Diploma & $22.2 \%$ & $8.4 \%$ \\
\hline Some College & $37.5 \%$ & $32.2 \%$ \\
\hline Bachelor's Degree & $34.7 \%$ & $47.7 \%$ \\
\hline Graduate Degree & $11.8 \%$ & $11.7 \%$ \\
\hline \multicolumn{3}{|l|}{ Income* } \\
\hline$<\$ 25,000$ & $20.7 \%$ & \\
\hline$\$ 25,001$ to $\$ 75,000$ & $10.7 \%$ & \\
\hline$\$ 75,001$ to $\$ 125,000$ & $22.4 \%$ & \\
\hline$>\$ 150,000$ & $17.3 \%$ & \\
\hline
\end{tabular}

*See Table 5 for a detailed breakdown of Income for Study 2

\subsection{Results}

The qualitative responses from the open-ended survey provide valuable insights into participants' perceived motivations to engage in access-based consumption. Two graduate assistants familiar with the research and trained in categorization techniques acted as independent coders to categorize the responses. In numerous instances, more than one reason was provided as to why the participant chose to engage in the behavior. Participants reporting more than one reason were grouped into multiple categories yielding 149 responses. Coding discrepancies were discussed between the coders; when a resolution was not reached the response was counted against the reliability assessment (Kassarjian, 1977). An additional 
researcher was brought in to discuss the response with the coders to determine the category if an agreement could not be reached. Inter-coder reliability was nearly 97 percent. The categorization of responses resulted in seven motivational categories. Five themes emerged as key factors influencing participants to engage in access-based consumption while two themes provided insight into why they may avoid engaging in this form of consumption.

The results of the qualitative study reveal several motivational factors that impact consumers when deliberating on whether to engage in access-based consumption. In particular, the economic benefits associated with short-term access were the most prevalent perceived positive motivation, as noted by a participant stating that "Renting certain items that are rarely used is a cost effective alternative to buying or owning. Tools are a great example." While saving money seems an intuitive motivation for access-based consumption, other motivations were also revealed: "It is a mutually beneficial situation. People who need an item can obtain it temporarily while owners, in the case of renting, can profit in some way off of unused items. Sharing and borrowing can benefit the environment and can help friends or family without cost." The positive environmental impact of product rentals is an important factor noted by many participants. Items being reused by multiple people or purposes is a positive environmental function, however other benefits were brought to light that one may not consider: "Renting, borrowing and sharing can reduce the amount of packaging that is wasted on new products."

Additionally, the ability to take a product on a "test run" without the responsibility of ownership was an important motivation noted by participants. One response noted that "Renting and borrowing is good because if you rent a product you do not like, you can always return it and the only thing you lose is the rental fee. Renting is also good if you want to try something out before you commit to buying it." It was noted by participants that given the abundance of product options in the marketplace, they like the ability to try things before they commit. The ability to experience something outside of the norm, or above what one would normally be able 
to experience, was another commonly noted reason. Given the prevalence and influence of variety seeking on consumption (Ratner, Kahn, \& Kahneman, 1999; Simonson, 1990), it was not surprising to have participants note they like "having a lot of new things to you and not having things get old." Responses often indicated the desire to seek status, as illustrated by "you can pretend to be someone you aren't for a day and do something that you may not otherwise get to do," which is made possible through access rather than ownership.

Moreover, some participants stated factors that may impede ones involvement in accessbased consumption. In some cases, respondents noted a preference for owning the item, rather than accessing it, indicating themes of possessiveness and materialism as deterrents. For instance, one participant noted: “They aren't yours, you can't keep them, there is a deadline on when to give them back, and it still costs money either way," while another responded that "The product is not yours and is essentially used. They could come with imperfections such as markings and missing features that a new product wouldn't come with." Furthermore, a few participants noted their low materialism as a reason for not accessing products: "I wouldn't be interested in this - I don't feel the need to rent materialistic items to impress others." This is contrary to existing research that suggests that those with low materialism would be more inclined to share resources and thus be more interested in access-based consumption (Belk, 1985, 2007; Kleine \& Baker, 2004). To better understand the motivations that influence participation in access-based services and the positive outcomes that result, a second study was developed to build upon these findings. 


\section{Study 2: Perceived Motivational Factors for Access-based Consumption}

In order to better understand the results of study one, and the themes that emerged, a quantitative study was conducted utilizing a different sample of respondents. This study examines the various motivational factors that emerged in the first study with the goal to provide an actionable framework for business practice. A cluster analysis was conducted to classify respondents' motivations surrounding access-based consumption (Hampson \& McGoldrick, 2013). Constructs examining economic consciousness, environmental consciousness, status consumption, possessiveness, and materialism were deemed appropriate given the findings from the qualitative study and previous research (Durgee \& O'Connor, 1995; Moeller \& Wittkowski, 2010; Barhdi \& Eckhardt, 2012; Belk, 2007). In addition, choice confusion, variety seeking, and loyalty are examined as they relate to the findings of flexibility and product trial uncovered in the first study.

\subsection{Motivations Impacting Access Based Consumption}

Both the findings from the first study and existing literature suggest that the constructs of economic consciousness, environmental consciousness and status consumption will motivate consumers to engage in access-based consumption. Economic consciousness is defined as "a consumer lifestyle trait characterized by the degree to which consumers are both restrained in acquiring and in resourcefully using economic goods and services to achieve longer-term goals" (Lastovicka, Bettencourt, Hughner, \& Kuntze, 1999). In addition, access-based services offer consumers the opportunity to support practices perceived as environmentally friendly (e.g., by sharing one vehicle among many consumers using Zipcar). Research suggests that environmentally conscious consumers are more likely to participate in environmentally friendly behaviors (Gleim \& Lawson, 2014; Hartmann \& Apaolaza-Ibáñez, 2012). Furthermore, status consumption is defined as, "the motivational process by which individuals strive to improve their social standing through the 
conspicuous consumption of consumer products that confer and symbolize status for both the individual and surrounding significant others" (Eastman, Goldsmith, \& Flynn, 1999, p. 42).

Further, we propose that the constructs of choice confusion, variety seeking, and loyalty capture the traits of consumers seeking flexibility and product trial, two key motivating factors identified in the first study. First, the ability to try a product before purchase can be an important consideration for consumers, in particular when product options are abundant. Choice confusion is characterized as a lack of certainty related to making choices based on a large number of options (Shim \& Gehrt, 1996). When consumers desire choice options, yet feel overwhelmed by the number of choices available, they may choose to postpone purchase, abandon the purchase or seek additional information (Schwartz, 2004; Matzler, Waiguny, \& Fuller, 2007). Accessbased consumption serves as a form of information search by allowing consumers to try a product before making the commitment of ownership, likely reducing the perceived risk of purchase (Locander \& Hermann, 1979). Accordingly, consumers are likely to prefer to try a product when they have choice confusion as it reduces their risk, thus leading to positive perceptions of access- based consumption.

Second, variety seeking is characterized by the degree to which a person expresses a desire to try new and different things (Donthu \& Gilliland, 1996). Consumers seek novelty, fun, and change through variety seeking behavior (Kahn, 1995). Access-based consumption allows individuals to experience the newest trends and products without the burdens of ownership or commitment to a specific style or brand (e.g., Rent the Runway, Borrowed Bling, and Bag, Borrow or Steal). However, product or brand loyalty could deter consumers from participating in access-based consumption given that consumers tend to consistently choose products they have had good experiences with in the past (Bendapudi \& Berry, 1997). Consumers who exhibit loyalty to a specific product or brand would be less likely to access products since they do not 
actively seek change. Accessing products may be a way for consumers to determine the products that they like, thus providing an alternate route to product loyalty.

Lastly, the responses to our open exploration of consumer motivations revealed two additional deterrents, suggesting that the constructs of possessiveness and materialism may negatively affect attitudes towards access-based consumption. Possessiveness is defined as a general attachment to possessions, while materialism is the importance a person attaches to those possessions (Belk, 1985). Possessiveness and materialism are related, as materialists believe that possessions are the key source of success and happiness in life (Felix \& Garza, 2012).

Accordingly, we propose that consumers who are highly attached to their possessions and rely on material objects as a source of happiness would not be as inclined to participate in access-based consumption given the importance they place on possessions.

\subsection{Sample and Data Collection}

Data was collected from self-report questionnaires completed by 220 adults using Amazon.com's Mechanical Turk (MTurk) online subject pool, which has been shown to be appropriate in terms of population characteristics and data quality (Berinsky, Huber, \& Lenz, 2012; Buhrmester, Kwang, \& Gosling, 2011). The goal was to collect data from a diverse set of respondents and was open to any adult with an MTurk account residing in the U.S. Potential respondents were shown a brief description of the survey: 'This study looks at accessing products or services through renting, borrowing, sharing, swapping, or lending. For example, this could be using UBER for transportation, AirBnB for lodging, etc.,' followed by more detailed information in the instructions. Respondents were paid a nominal fee for completing the survey. Demographic information for the sample can be found in Table 1.

\subsection{Procedures and Data Analysis}

Preliminary data analysis resulted in a reduced sample. In total, six questionnaires were 
removed from the study. Questionnaires were eliminated from the study for leaving questions blank or for failing to properly answer a quality check question. Several steps were also taken to ensure that common method bias had minimal effects on the findings. A pretest was conducted using a sample of undergraduate business students to ensure scale items were clear and not ambiguous (Podsakoff, MacKenzie, Lee, \& Podsakoff, 2003). In addition, respondents were assured of their anonymity, while the independent and dependent variables were spatially separated (Podsakoff, et al., 2003; Lindell \& Whitney, 2001). The online survey questions for each construct appeared in random order for each respondent in an effort to eliminate order effects.

\subsection{Measures}

All scales used in the study were adapted from existing literature and modified to fit the current research. The online survey instrument included measures to assess the following constructs: (1) economic consciousness (Lastovicka, et al., 1999), (2) environmental consciousness (Weigel \& Weigel, 1978), (3) status consumption (Eastman, et al., 1999), (4) choice confusion (Shim \& Gehrt, 1996), (5) variety seeking (Donthu \& Gilliland, 1996), (6) loyalty (Jacoby \& Kyner, 1973), (7) possessiveness (Belk, 1985), (8) materialism (Richins \& Dawson, 1992), (9) attitude toward access-based consumption (Richins, 1997) and (10) behavioral intentions toward access-based consumption (Teo, 2002).

\subsection{Measurement Model}

The psychometric properties of the items were evaluated through a comprehensive confirmatory factor analysis (CFA). All items were simultaneously tested in one model and were restricted to load on their assigned factors. The results of the confirmatory factor analysis are identified in Table 3. Due to the sensitivity of chi-square to sample size, the model fit was evaluated using the root mean square error of approximation (RMSEA), the comparative fit index (CFI), and the Tucker-Lewis index (TLI). These fit indices were identified based on their 
relative stability and insensitivity to sample size (Hu \& Bentler, 1999; Gerbing \& Anderson, 1992).

The measurement model fit the data well $\left(\chi^{2}=719.66, \mathrm{~d} f=389, \mathrm{RMSEA}=.06, \mathrm{CFI}=\right.$ .93$, TLI $=.92)$. Reliability was measured via the composite reliability (Fornell \& Larcker, 1981) with results indicating that the constructs were reliable as each approached or exceeded the recommended rule of thumb of 0.70 (Nunnally, 1978). All scales were reliable with construct reliability estimates ranging from .68 to .94 . Convergent validity was evaluated through an examination of the average variances extracted (see Table 2). All of the average variances extracted were greater than .50, indicating convergent validity (Fornell \& Larcker, 1981). Discriminant validity was tested in accordance with Fornell and Larcker's (1981) criteria, whereby the average variance extracted for the construct was compared with the shared variance between the construct and other variables in the model. The results indicate discriminant validity for all of the squared correlations, as evidenced by the average variance extracted by each of the scales being greater than the shared variance between the constructs. Given the positive results from the measurement model, a cluster analysis was conducted per Punj and Stewart (1983). As this research is exploratory in nature and seeks to better understand the motivations surrounding access-based consumption, a cluster analysis was deemed the appropriate method of analysis (e.g., Gleim, Smith, Andrews, \& Cronin, 2013). 
Table 2

Measurement Model Results

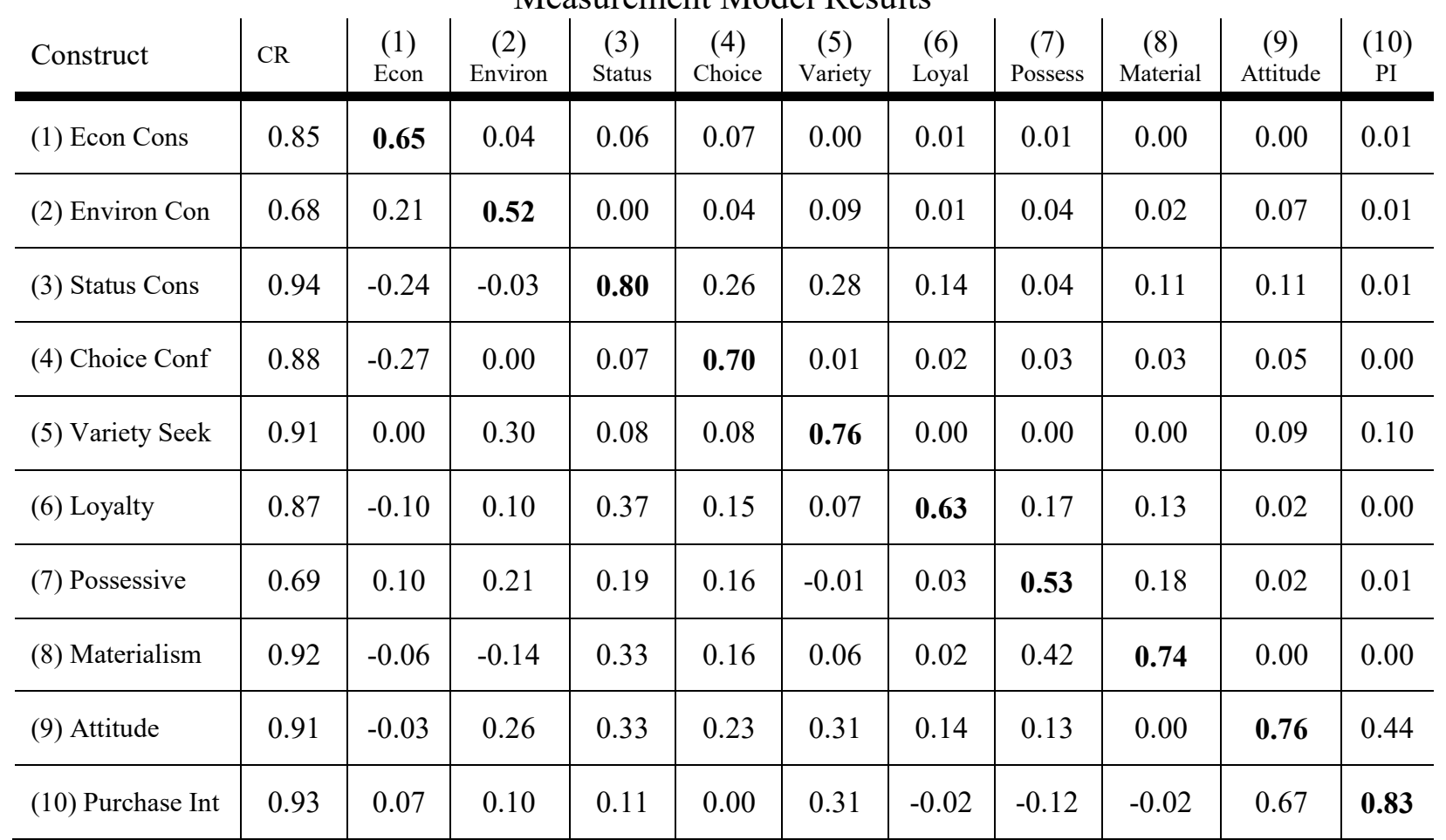

Note: $\chi^{2}=719.66, \mathrm{~d} f=389$, RMSEA $=.06, \mathrm{CFI}=.93$, TLI $=.92$ Correlations are shown below the diagonal; shared variances are depicted above the diagonal; the AVE is depicted in boldface on the diagonal.

\subsection{Results}

A two-step cluster analysis procedure was conducted in order to categorize sample respondents based on responses to the clustering variables (Punj \& Stewart, 1983). Respondents were assigned a label based on their attitude and purchase intentions toward access-based consumption. The respondents were segmented on the complete set of variables and labeled according to the dependent variables' values. The initial step in the clustering procedure was to analyze the data (214 observations) via a hierarchical cluster analysis using multiple clustering algorithms (e.g., centroid, Ward's method) and Squared Euclidean distance to effectively determine the number of clusters. An examination of relevant statistics (e.g., R-square, agglomeration coefficients) and the dendrogram were utilized to determine the number of clusters (Sharma, 1996). The second step utilized a non-hierarchical technique (i.e., k-means) using the initial seed points generated from utilizing the results obtained via Ward's method to create an improved solution (Punj \& Stewart, 1983). 
The cluster analysis identified a four-cluster solution as the most interpretable in terms of practical relevance. The four groups were segmented based their attitudes toward access-based consumption and labeled "Fickle Floaters," "Premium Keepers," "Conscious Materialists" and "Change Seekers." In addition, follow-up analyses (e.g., MANOVA and chi-square tests) were conducted to assess differences between the clusters. The Tukey pairwise comparisons indicated significant differences in centroid means across the independent variables, as suggested by the differences between segments as identified in Table 3. The differences between segments on the outcome measures of attitude and purchase intentions are identified in Table 4. In addition, demographic information (see Table 5), the types of products accessed (i.e., public, private, hedonic, utilitarian), and the rental ratios (average of the rental price of an item for a specified rental period divided by the purchase price) of the products are examined as well (see Table 6).

The rental ratios were determined through a systematic procedure. Online searches were conducted based on the information provided by the respondents. If information for a product accessed at a specific site was provided, then that specific website was used to determine the rental price and a Google search was done to determine the purchase price for the same item. If no specific website was given, a Google search was conducted to find the access-based business and purchase price. If the product information provided for an item was too vague it was not included. The rental price and purchase price for nearly 100 items were found, or approximately 25 items per cluster. 
Table 3

Consumer Characteristics by Cluster

\begin{tabular}{|c|c|c|c|c|c|}
\hline & $\begin{array}{l}\text { "Fickle } \\
\text { Floaters" }\end{array}$ & $\begin{array}{l}\text { "Premium } \\
\text { Keepers" }\end{array}$ & $\begin{array}{l}\text { "Conscious } \\
\text { Materialists" }\end{array}$ & $\begin{array}{l}\text { "Change } \\
\text { Seekers" }\end{array}$ & \\
\hline Clustering & $\begin{array}{c}\text { Cluster } 1 \\
(\mathrm{n}=45)\end{array}$ & $\begin{array}{c}\text { Cluster } 2 \\
(\mathrm{n}=71)\end{array}$ & $\begin{array}{c}\text { Cluster } 3 \\
(\mathrm{n}=52)\end{array}$ & $\begin{array}{c}\text { Cluster } 4 \\
(\mathrm{n}=46)\end{array}$ & $\begin{array}{c}\mathrm{F}=\text { Value } \\
(\mathrm{p}= \\
\text { probability })\end{array}$ \\
\hline $\begin{array}{l}\text { Econ. Cons. } \\
\text { Cluster Mean }\end{array}$ & $6.22(3)$ & $5.77(1,2)$ & $6.24(3)$ & $6.16(-)$ & 3.7 \\
\hline Rank & 1 & 1 & 1 & 1 & $(\mathrm{p}<.05)$ \\
\hline $\begin{array}{l}\text { Environ. Cons } \\
\text { Cluster Mean }\end{array}$ & $4.23(2,3,4)$ & $5.06(1)$ & $5.15(1)$ & $5.09(1)$ & 4.16 \\
\hline Rank & 2 & 3 & 3 & 3 & $(\mathrm{p}<.05)$ \\
\hline $\begin{array}{l}\text { Status Cons. } \\
\text { Cluster Mean }\end{array}$ & $1.7(3)$ & $4.19(1,2,4)$ & $2(3)$ & $2.22(3)$ & 73.36 \\
\hline Rank & 8 & 7 & 8 & 7 & $(p<.001)$ \\
\hline $\begin{array}{l}\text { Choice Conf. } \\
\text { Cluster Mean }\end{array}$ & $2.81(3)$ & $4.01(1,2,4)$ & $3.31(3)$ & $2.99(2)$ & 8.27 \\
\hline Rank & 6 & 8 & 6 & 5 & $(\mathrm{p}<.001)$ \\
\hline $\begin{array}{l}\text { Variety Seek. } \\
\text { Cluster Mean }\end{array}$ & $4.07(2,3,4)$ & $5.36(1)$ & $5.08(1)$ & $5.54(1)$ & 15.37 \\
\hline Rank & 3 & 2 & 4 & 2 & $(\mathrm{p}<.001)$ \\
\hline $\begin{array}{l}\text { Loyalty } \\
\text { Cluster Mean }\end{array}$ & $2.69(3)$ & $4.45(1,2,4)$ & $2.25(3,4)$ & $3.14(2,3)$ & 34.29 \\
\hline Rank & 7 & 5 & 7 & 4 & $(\mathrm{p}<.001)$ \\
\hline $\begin{array}{l}\text { Possessiveness } \\
\text { Cluster Mean }\end{array}$ & $3.69(4)$ & $4.2(4)$ & $4.41(4)$ & $2.71(1,2,3)$ & 14.42 \\
\hline Rank & 5 & 6 & 5 & 6 & $(\mathrm{p}<.001)$ \\
\hline $\begin{array}{l}\text { Materialism } \\
\text { Cluster Mean } \\
\end{array}$ & $3.74(2,3)$ & $5.03(1,3,4)$ & $5.29(1,3,4)$ & $2.47(2,3)$ & 55.58 \\
\hline Rank & 4 & 4 & 2 & 7 & $(\mathrm{p}<.001)$ \\
\hline
\end{tabular}

Note: The numbers in parentheses show the group number(s) from which this group was significantly different at the 0.05 level of significance based on the Tukey pairwise comparison tests. The rank indicates the rank order of the variable within the cluster group. 
Table 4

\begin{tabular}{c|c|c|c|c|c} 
& \multicolumn{4}{|c}{ Outcome Measure Results by Cluster } \\
& $\begin{array}{c}\text { "Fickle } \\
\text { Floaters" }\end{array}$ & $\begin{array}{c}\text { "Conscious } \\
\text { Materialists" }\end{array}$ & $\begin{array}{c}\text { "Premium } \\
\text { Keepers" }\end{array}$ & $\begin{array}{c}\text { "Change } \\
\text { Seekers" }\end{array}$ & $\begin{array}{l}\text { F= Value } \\
\text { (p = } \\
\text { probability })\end{array}$ \\
\hline & Cluster 1 & Cluster 2 & Cluster 3 & Cluster 4 & \\
\hline $\begin{array}{c}\text { Attitude } \\
\text { Cluster Mean }\end{array}$ & $2.73(2,3,4)$ & $4.58(1,4)$ & $4.94(1)$ & $5.23(1,2)$ & $\begin{array}{c}50.2 \\
(\mathrm{n}<.001)\end{array}$ \\
\hline $\begin{array}{c}\text { Purchase Intention } \\
\text { Cluster Mean }\end{array}$ & $2.27(2,3,4)$ & $4.65(1,4)$ & $4.38(1,4)$ & $5.34(1,2,3)$ & $\begin{array}{c}54.79 \\
(\mathrm{p}<.001)\end{array}$ \\
\hline
\end{tabular}

Note: The numbers in parentheses show the group number(s) from which this group was significantly different at the 0.05 level of significance based on the Tukey pairwise comparison tests. 
Table 5

Demographic Information by Cluster

\begin{tabular}{|c|c|c|c|c|}
\hline & $\begin{array}{l}\text { "Fickle } \\
\text { Floaters" }\end{array}$ & $\begin{array}{l}\text { "Premium } \\
\text { Keepers" }\end{array}$ & $\begin{array}{l}\text { "Conscious } \\
\text { Materialists" }\end{array}$ & $\begin{array}{l}\text { "Change } \\
\text { Seekers" }\end{array}$ \\
\hline Demographics & (1) & (2) & (3) & (4) \\
\hline Mean Age & 40 & 33.9 & 37.5 & 35.8 \\
\hline \multicolumn{5}{|l|}{ Sex $(\%)$} \\
\hline Male & 57.8 & 66.2 & 51.9 & 56.5 \\
\hline Female & 42.2 & 33.8 & 48.1 & 43.5 \\
\hline \multicolumn{5}{|l|}{ Ethnicity (\%) } \\
\hline African American & 6.7 & 8.5 & 5.8 & 8.7 \\
\hline Asian & 4.4 & 19.7 & 5.8 & 6.5 \\
\hline Caucasian & 86.7 & 66.2 & 80.8 & 76.1 \\
\hline Hispanic & 0 & 5.6 & 3.8 & 6.5 \\
\hline Other & 2.2 & 0 & 3.8 & 2.2 \\
\hline Education (\%) & $M=2.67$ & $M=2.68$ & $\mathrm{M}=2.48$ & $\mathrm{M}=2.74$ \\
\hline High School Diploma & 8.9 & 7 & 11.5 & 6.5 \\
\hline Some College & 31.1 & 25.4 & 46.2 & 28.3 \\
\hline Bachelor's Degree & 44.4 & 62 & 28.8 & 52.2 \\
\hline Master's Degree & 15.6 & 5.6 & 9.6 & 10.9 \\
\hline Terminal Degree & 0 & 0 & 3.8 & 2.2 \\
\hline Income $(\%)$ & $\mathrm{M}=2.20$ & $M=2.68$ & $M=2.02$ & $M=2.85$ \\
\hline$<\$ 25,000$ & 31.1 & 19.7 & 36.5 & 15.2 \\
\hline$\$ 25,001$ to $\$ 50,000$ & 35.6 & 31 & 40.4 & 32.6 \\
\hline$\$ 50,001$ to $\$ 75,000$ & 20 & 19.7 & 9.6 & 21.7 \\
\hline$\$ 75,001$ to $\$ 100,000$ & 11.1 & 21.1 & 11.5 & 17.4 \\
\hline$\$ 100,001$ to $\$ 150,000$ & 0 & 8.5 & 2 & 8.7 \\
\hline$>\$ 150,000$ & 2.2 & 0 & 0 & 4.3 \\
\hline Household Size & 2.1 & 2.5 & 2.5 & 2.6 \\
\hline
\end{tabular}

*M = Mean 
Table 6

Product Information by Cluster

\begin{tabular}{l|c|c|c|c} 
& $\begin{array}{c}\text { "Fickle } \\
\text { Floaters" }\end{array}$ & $\begin{array}{c}\text { "Premium } \\
\text { Keepers" }\end{array}$ & $\begin{array}{c}\text { "Conscious } \\
\text { Materialists" }\end{array}$ & $\begin{array}{c}\text { "Change } \\
\text { Seekers" }\end{array}$ \\
\hline Product Type & $(1)$ & $(2)$ & $(3)$ & $(4)$ \\
\hline Private & & & & \\
\hline Public & $29.80 \%$ & $39.50 \%$ & $23.30 \%$ & $32.30 \%$ \\
\hline & $70.20 \%$ & $60.50 \%$ & $76.70 \%$ & $67.70 \%$ \\
Hedonic & $67.30 \%$ & $66.10 \%$ & $82.20 \%$ & $75.70 \%$ \\
\hline Utilitarian & $32.70 \%$ & $33.90 \%$ & $17.80 \%$ & $24.30 \%$ \\
\hline Rental Ratio* & & & & \\
\hline
\end{tabular}

*Rental Ratio reflects the average of the rental price of an item for a specified rental period divided by the purchase price.

Cluster 1, "Fickle Floaters," is comprised of 45 individuals (21.0 percent of the sample) that have the lowest attitude and purchase intentions toward access-based consumption. This segment is comprised of individuals who do not seek status, have low levels of brand loyalty, and who make choices easily, suggesting they float from product to product with little loyalty to any particular brand. This segment scores highest on economic consciousness, but is the lowest on environmental consciousness, status consumption, choice confusion and variety seeking.

Possessiveness and materialism also score quite low for this segment. In addition, this segment has the highest average age, and is largely comprised of well-educated Caucasian males earning the second lowest average income. This segment tends to consume public goods that are hedonic in nature at the lowest rental ratio of any segment.

Cluster 2, "Premium Keepers," is comprised of 71 individuals (33.2 percent of the sample) who score lowest on economic consciousness, but highest on status consumption, 
choice confusion and loyalty, suggesting that once these individuals find a product they like they are loyal even if it is more expensive. Individuals in this segment also score high on environmental consciousness, possessiveness and variety seeking. This segment is the youngest and dominated by males, but has the most ethnic diversity. This segment is well educated, has the second highest average income and has a larger average household size than the "Fickle Floaters." Moreover, this segment is the highest on private and utilitarian product consumption and has the highest average rental ratio. While these individuals have a positive attitude about access-based consumption (second highest score), they have lower intentions of utilizing these services. These individuals like the idea of access-based consumption more than they actually use the services, and instead are more likely to outright purchase products.

Cluster 3, "Conscious Materialists," is comprised of 52 individuals (24.3 percent of the sample) who score the second highest on purchase intentions toward access-based consumption. This group scores the highest on economic and environmental consciousness, possessivenessand materialism, but the lowest on loyalty. This group appears to seek variety, but not status and has issues making decisions. In addition, it has the second oldest average age, is quite even on gender make-up, but tilted toward the Caucasian ethnicity. This segment is also the least educated and has the lowest income. It seeks more public and hedonic goods than any other segment and has the second lowest rental ratio. This group appears to value material possessions, while simultaneously seeking to be economically and environmentally conscious.

Lastly, cluster 4, "Change Seekers," is comprised of 46 individuals (21.5 percent of the sample) who score the highest on attitude and purchase intentions toward access-based consumption. These individuals seek variety more than any other group, and are the least possessive and materialistic. This group is also low on status consumption and choice confusion, but high on environmental and economic consciousness. In addition, this segment is the second youngest, comprised of more males than females and quite ethnically diverse. This segment has 
the highest average education and income, plus has the largest average household size. This segment has the second highest private and hedonic product consumption rate, as well as the second highest rental ratio. Figure 1 summarizes the segmentation framework by cluster while Figure 2 visually depicts product type (hedonic/utilitarian and public/product), as well as rental ratio by cluster.

Figure 1

Cluster-based Segmentation Framework

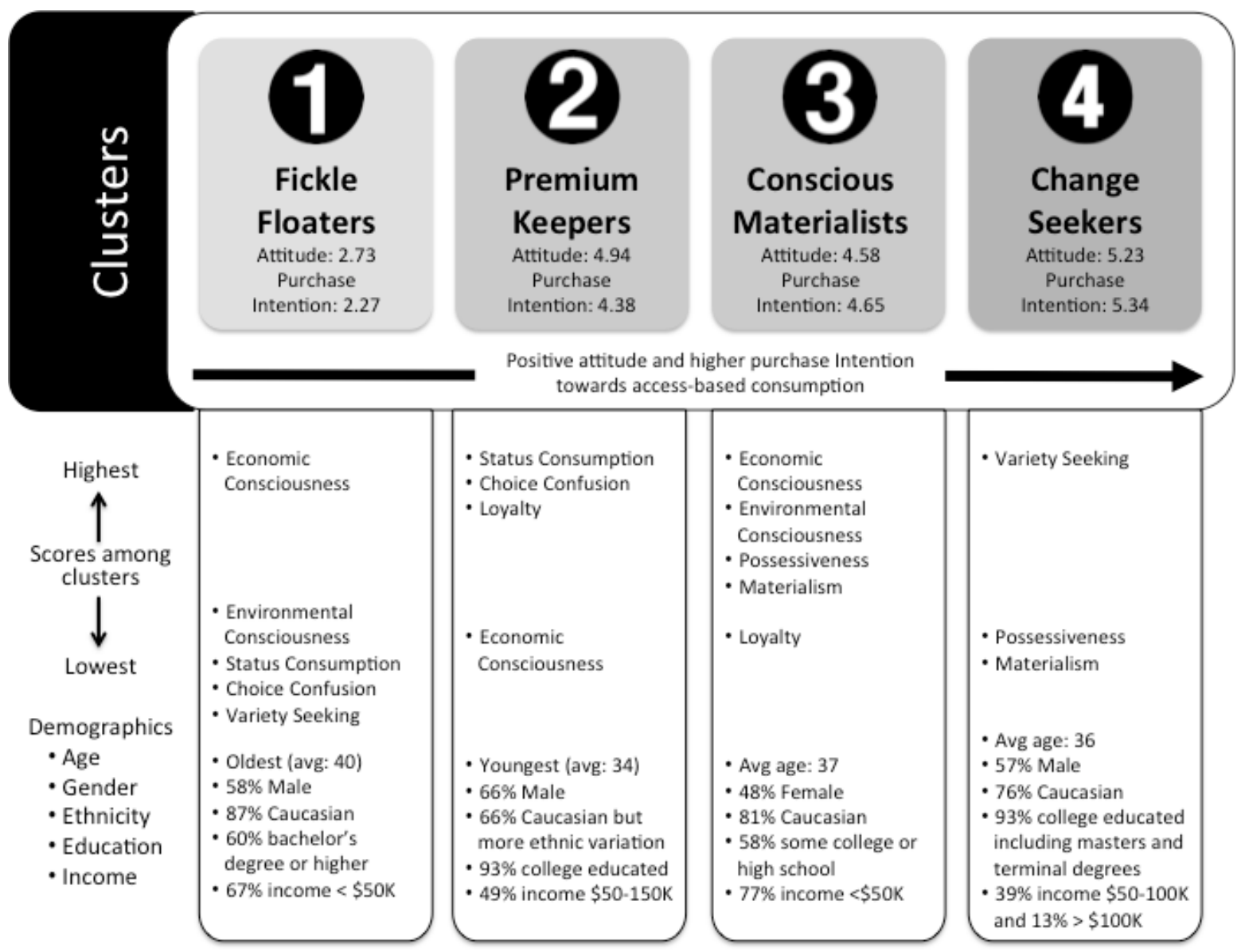


Figure 2

Product Type and Use by Cluster

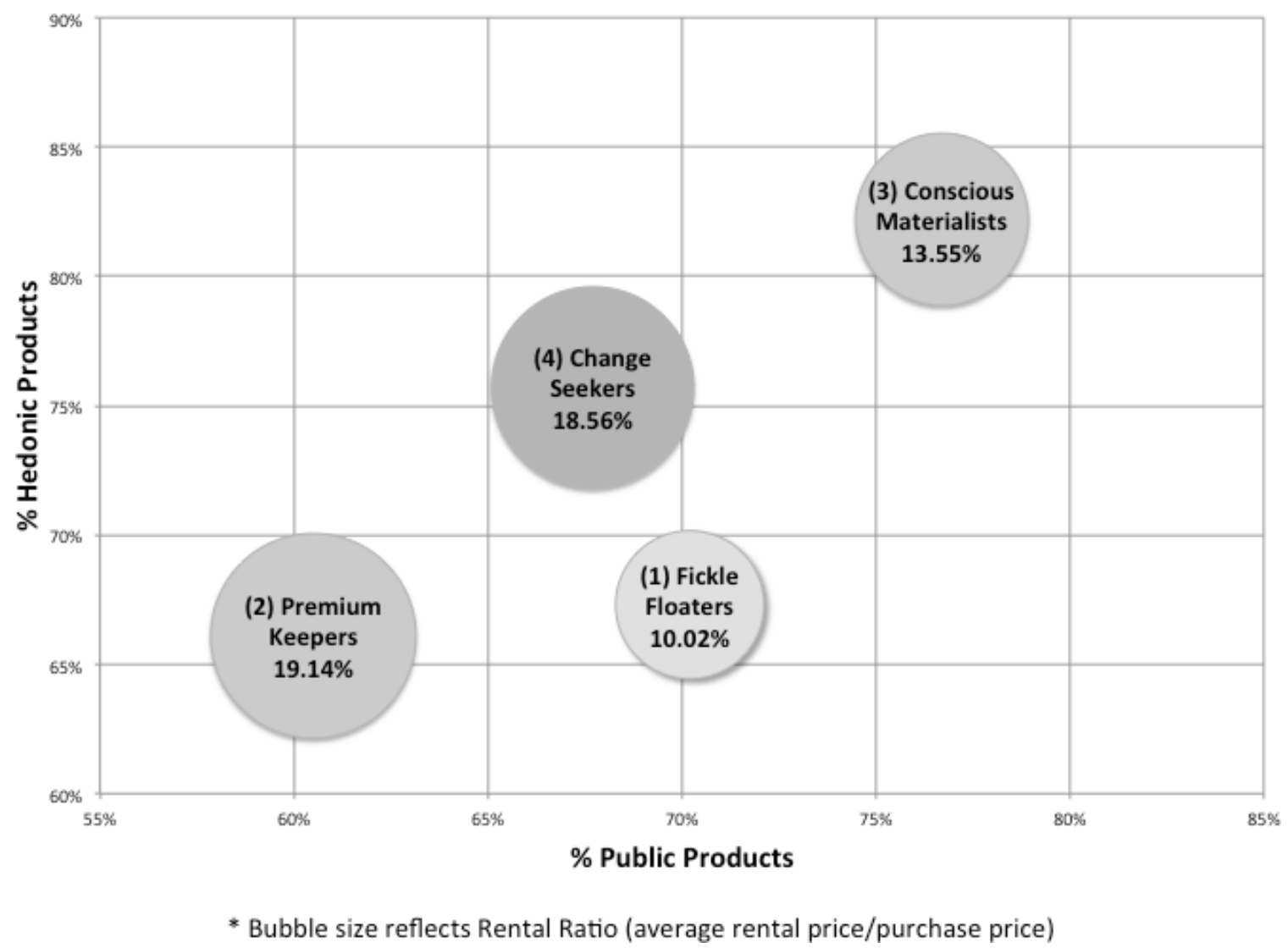

\section{Discussion and Implications}

The present research explores the emerging trend of access-based consumption by examining the factors leading to consumer adoption. First, a qualitative inquiry examined the motivations that favor and hinder access-based consumption followed by a larger scale quantitative study that used cluster analysis to produce an actionable segmentation framework for business practice. The findings suggest that access-based consumers can generally be classified into one of four segments, each with its own unique characteristics and varying dispositions towards access-based consumption.

The segment least likely to access products, "Fickle Floaters," appears to be driven primarily by price. Given the economic consciousness of this segment, one may expect that the 
lower prices offered through access would be appealing, as evidenced by the low rental ratio of about $10 \%$ for this group of consumers. Further, this segment tends to seek public and hedonic products to access, while also being open to utilitarian options. Thus, access-based firms attempting to sway consumers in this segment need to realize that the rental price is the key influencer, coupled with the type of product offered. Access-based firms like Spinlister, which offer sports equipment access, and JustPark, which offers access to privately-owned parking spaces, are uniquely positioned to appeal to consumers seeking public products at a low cost.

In addition, the demographics of this segment may play a role in ones willingness to access products. The average age of this segment is much higher than all of the others, suggesting that either products targeting this age group are not available or they do not feel comfortable utilizing the technology necessary to access products, despite being a quite well educated group of consumers. Tapping into this segment of consumers may be the most challenging, however it could also be very rewarding. These consumers are the least likely to access products, thus established brands could leverage their reputation and economies of scales to provide the products sought at an acceptable price to tap into this market of consumers. For example, Home Depot's tool and truck rental program is able to offer a "best price guarantee" and leverage its reputation to appeal to this segment. The rental process is completed in-store making it more attractive to the demographics of this group. Firms like Home Depot offering access to a chainsaw retailing for over $\$ 700$ for $\$ 65$ a day, would not only be able to draw in customers seeking access, but it may also draw in a more permanent retail customer as well. Perhaps one of the most attractive segments for firms to pursue is the "Premium Keepers" as they are the least economically conscious. These consumers have a very favorable attitude toward accessing products; yet have much lower intentions of actually doing so. The favorable attitude is not surprising since this segment has issues making decisions and seeks variety and 
status. However, the possessive and materialistic nature of this segment, coupled with being less economically conscious, explains why these consumers would rather own items than access them. Additionally, the higher average income allows this segment the option to own rather than access. With a rental ratio approaching $20 \%$, it is clear these consumers are willing to pay for products they desire. Access-based firms that offer practically any type of product have an opportunity to capitalize on this group by touting the status and variety of the products offered, while minimizing choice confusion. For example, companies like Gwynnie Bee for clothing, can leverage the variety and status of the products available, plus offer product suggestions and recommendations to help nurture loyalty among this segment.

Additionally, while females are more likely to engage in access-based consumption, research suggests opportunity exists with male consumers as well (van de Glind, 2013). This segment is ripe with opportunity to capture the male market. Items such as computers or televisions, which generally have a higher rental ratio, would likely be very appealing to this segment. Firms like Flying Connected, that offer iPad access, can capitalize on this segment's desire to seek status through "an experience that stands out from the rest" (http://www.flyingconnected.com/ipad-rentals). This segment has the income required to access the products they seek, thus making for a very appealing customer base. Firms seeking to attract this consumer segment can position their offerings in ways that promote the aspirational qualities of their products, thus, incentivizing those seeking status to try the access-based firm.

The environmental benefit of access-based consumption is something that many firms market heavily and that could be very important to a group like the "Conscious Materialists." These consumers are very environmentally conscious, despite being highly possessive and materialistic. Given that access-based firms can reduce the environmental impact by increasing 
product utility through the maximization of idle capacity, it is an important message to make known to potential customers. For example, it is estimated that for every car used in a sharing initiative, like ZipCar, approximately 8-10 vehicles are taken off the road (Trendwatching.com, 2006). Thus, firms need to recognize the environmentally friendly attributes they offer and make sure potential customers understand those benefits.

While access-based firms should remain aware that the general attachment to goods may be an inhibiting factor for these individuals, it may not be the barrier that was originally expected. Since access-based consumption allows a consumer to try a variety of products, appealing to those wanting to stay up to date with the latest trends (especially in fashion and technology) the role of possessiveness and materialism may be minimal. Access-based firms like Rent the Runway, which offer on-trend clothing, and DriveNow, which offer access to luxury BMW cars, are uniquely positioned to appeal to the variety and status-seekingconsumer. Thus, a market of consumers who relish the opportunity to refresh their wardrobes and electronics on a more frequent basis, while avoiding the inherent risk of obsolescence, exists.

Despite having the lowest average income, these consumers tend to seek hedonic products that are publically consumed. The low rental ratio suggests that price is an important issue for these consumers. Firms such as Airbnb, that offer access to vacation rentals at an affordable price, or Zipcar who offer short-term car access are poised to capture this segment of consumers. Individuals not only desire to access products, but they seek the benefit that visibility offers when accessing public goods in an environmentally friendly manner. Thus, access-based firms should emphasize the value of their offerings, which may be publically consumed, and seize the opportunity to capitalize on consumers seeking sustainable benefits without the tradeoffs commonly associated with "going green."

The most likely segment to access products, "Change Seekers," seek variety more than any other segment and are the least possessive and materialistic. For an access-based business, 
this is a very appealing consumer profile. Couple that with being well educated and having the highest income levels and household size, this segment offers firms a tremendous opportunity. Current access-based business models provide consumers access to a variety of products at lower costs in a way that was impossible in the past. Access-based services can attract variety-seeking consumers by emphasizing how their innovative service offerings provide opportunities to try a variety of new products without committing to a specific one and without spending a lot of money to do so. Access-based firms seeking to appeal to this segment should clearly explain how the process works and emphasize the lack of commitment that is required. Access-based firms like Boatbound, which offer access to boats for the day with or without captains, are ideally set up for segment of consumers.

Given the average household size of not only this segment, but the previous two as well, an opportunity that exists could be families. For example, Pley offers monthly toy access based on a child's developmental stage: "your kids get to play with the coolest toys and you can save money, reduce clutter and help the environment" (https://www.pley.com/toy-rental). As children reach developmental milestones their toy needs and preferences outpace the durability of most toys, thus access-based consumption offers a way for parents to regularly introduce new toys without excessive spending and waste (Catulli, Lindley, Reed, Green, Hyseni, \& Kiri, 2013; Ozanne \& Ballantine, 2010).

Overall, the research presented suggests that while economics play a large role in attitudes regarding access-based consumption, additional factors play an important role. Currently, most access-based service providers tout their offerings as hassle free and less costly, while others emphasize the environmental or societal benefits. Understanding consumer profiles that seek access rather than ownership is critical for firms seeking to effectively target and position their offerings to this growing market of consumers. This research provides an 
actionable framework access-based firms can utilize for market segmentation and strategy development.

\section{Limitations and Future Research}

The results of this research contribute to the understanding of access-based consumption; however it is not without limitations. The data for the second study was collected from single sources measuring behavioral intentions rather than actual usage for the dependent variables. However, we did attempt to incorporate the actual items accessed into the analysis as to provide a more accurate picture. Additionally, the research is limited to the variables selected to represent the themes that emerged from the qualitative study, as well as the current related theory. Other constructs may provide additional insight into the drivers of consumer attitudes and intentions toward access-based consumption and should be considered for future research. Further, the results of the cluster analysis could yield different results depending on the algorithm used. The method reported is often considered the most robust and the results provide practical relevance.

Many additional opportunities exist for future research related to access-based consumption. Investigating the influence of price and the subsequent impact on consumers' willingness to access products appears to be paramount. Understanding how access-based consumption influences conversion to ownership could help businesses understand the impact of the trial aspect of access-based service offerings. Companies offering their products through access-based service providers would be interested to know if consumer brand loyalty shifts from the product brand to the access-based service provider brand. Exploring the relationships between environmentally friendly advertising, access-based consumers and their perceptions of authenticity would provide organizations with insight into the effectiveness of strategic initiatives related to green marketing. The framework provided in this research could be used to compare the effectiveness of initiatives across market segments.

In addition, researchers could examine how product option presentation impacts 
consumers. In particular, understanding how product characteristics like hedonic versus utilitarian or public versus private consumption influence consumer choice should be investigated. Research examining product offerings that are less gender-specific and appeal to a broader audience would help firms to better understand the marketplace in which they are competing. Likewise, more research is needed to understand the relationship between accessbased consumption and materialism. The results of this study suggest that this relationship is not as straightforward as formerly understood. Perhaps consumers perceive accessed possessions differently from owned possessions and thus, high levels of materialism do not preclude them from participation. The findings of this research provide marketers with insight into accessbased consumption and lay the foundation for future research on this exchange phenomenon.

\section{Rererences}

Bardhi, F., \& Eckhardt, G.M. (2012). Access based consumption: the case of car sharing. Journal of Consumer Research, 39 (4), 881-898.

Belk, R.W. (1985). Materialism: trait aspects of living in the material world. Journal of Consumer Research, 12 (3), 265-280.

Belk, R.W. (2007). Why not share rather than own? The ANNALS of the American Academy of Political and Social Science, 611, 126-140.

Belk, R.W. (2014). You are what you can access: Sharing and collaborative consumption online. Journal of Business Research, 67(8), 1595-1600.

Bendapudi, N., \& Berry, L. L. (1997). Customers' motivations for maintaining relationships with service providers. Journal of Retailing, 73(1), 15-37

Berinsky, A.J., Huber, G.A., \& Lenz, G.S. (2012). "Evaluating Online Labor Markets for Experimental Research: Amazon.com's Mechanical Turk," Political Analysis, 20 (3), 351-68.

Botsman, R., \& Rogers, R. (2010). What's mine is yours: the rise of collaborative consumption. New York: HarperCollins.

Buhrmester, M.D., Kwang, T., \& Gosling, S.D. (2011). Amazon's Mechanical Turk: A New Source of Inexpensive, Yet High-Quality, Data? Perspectives on Psychological Science, 6(1), 35.

Catulli, M., Lindley, J.K., Reed, N.B., Green, A., Hyseni, H., \& Kiri, S. (2013). What is mine is not yours: Further insight on what access-based consumption says about consumers, in Russell 
W. Belk, Linda Price, Lisa Peñaloza (ed.) Consumer Culture Theory (Research in Consumer Behavior, Vol. 15) Emerald Group Publishing Limited, 85 - 208.

Donthu, N., \& Gilliland, D. (1996). The infomerical shopper. Journal of Advertising Research, 36 (March/April), 69-76.

Durgee, J.F., \& O’Connor, G.C. (1995). An exploration into renting as consumption behavior. Psychology and Marketing, 12(2), 89-104.

Eastman, J.K., Goldsmith, R.E., \& Flynn, L.R. (1999). Status consumption in consumer behavior: scales development and validation. Journal of Marketing Theory and Practice, 7, 4152.

Felix, R., \& Garza, M.R. (2012). Rethinking Worldly Possessions: The Relationship between Materialism and Body Appearance for Female Consumers in an Emerging Economy. Psychology \& Marketing, 29(12), 980-994.

Fornell, C., \& Larker, D.F. (1981). Evaluating structural equation models with unobservable variables and measurement error. Journal of Marketing Research, 18, 39-50.

Gerbing, D.A., \& Anderson, J.C. (1992). Monte Carlo evaluations of goodness of fit indices for structural equation models. Sociological Methods and Research, 21(2), pp. 132-160.

Gleim, M.R., \& Lawson, S.J. (2014). Spanning the gap: an examination of the factors leading to the green gap. Journal of Consumer Marketing, 31(6/7), 503-514.

Gleim, M.R., Smith, J.S., Andrews, D., \& Cronin, J.J. (2013). Against the Green: A Multimethod Examination of the Barriers to Green Consumption. Journal of Retailing, 89 (1), 44-61.

Hampson, D. P., \& McGoldrick, P. J. (2013). A typology of adaptive shopping patterns in recession. Journal of Business Research, 66(7), 831-838.

Hartmann, P., \& Apaolaza-Ibáñez, V. (2012). Consumer attitude and purchase intention toward green energy brands: The roles of psychological benefits and environmental concern. Journal of Business Research, 65(9), 1254-1263.

Hu, L., \& Bentler, P.M. (1999). Cutoff criteria for fit indexes in covariance structure analysis: Conventional criteria versus new alternatives. Structural Equation Modeling, 6(1), 1-55.

Jacoby, J., \& Kyner, D. B. (1973). Brand loyalty vs. repeat purchasing behavior. Journal of Marketing Research, 1-9.

Kahn, B. (1995). Consumer variety-seeking among goods and services. Journal of Retailing and Consumer Services, 2(3), 139-148.

Kassarjian, H.H. (1977). Content analysis in consumer research. Journal of Consumer Research, 4 (June), 8-18.

Kleine, S.S., \& Baker, S.M. (2004). An integrative review of material possession attachment. 
Academy of Marketing Science Review, 1, 1-39.

Lamberton, C., \& Rose, R. (2012). When is ours better than mine? A framework for understanding and altering Participation in commercial sharing systems. Journal of Marketing, 76(4), 109-125.

Lastovicka, J.L., Bettencourt, L.A., Hughner, R.S., \& Kuntze, R.J. (1999). Lifestyles of the tight and frugal: Theory and measurement. Journal of Consumer Research, 26(1), 85-98.

Lindell, M.K., \& Whitney, D.J. (2001). Accounting for common method variance in crosssectional research designs. Journal of Applied Psychology, 86(1), 114-121.

Locander, W.B., \& Hermann, P.W. (1979). The effect of self-confidence and anxiety on information seeking in consumer risk reduction. Journal of Marketing Research, 16 (May), 268274.

Matzler, K., Waiguny, M., \& Fuller, J. (2007). Spoiled for choice: Consumer confusion in internet-based mass customization. Innovative Marketing, 3(3), 7-18.

Moeller, S., \& Wittkowski, K. (2010). The burdens of ownership: Reasons for preferring renting. Managing Service Quality, 20(2), 176-191.

Meuter, M.L., Ostrom, A.L., Roundtree, R.I., \& Bitner, M.J. (2000). Self-service technologies: Understanding customer satisfaction with technology-based service encounters. Journal of Marketing, 64(3), 50-64.

Nunnally, J.C. (1978). Psychometric Theory (2 $2^{\text {nd }}$ ed.). New York: McGraw-Hill.

Ozanne, L.K., \& Ballantine, P.W. (2010). Sharing as a form of anti-consumption? An examination of toy library users. Journal of Consumer Behaviour, 9(6), 485-498.

Podsakoff, P.M., MacKenzie, S.B., Lee, J.Y., \& Podsakoff, N.P. (2003). Common method bias in behavioral research: A critical review of the literature and recommended remedies. Journal of Applied Psychology, 88(5), 879-903.

Punj, G., \& Stewart, D.W. (1983). Cluster analysis in marketing research: Review and suggestions for application. Journal of Marketing Research, 20(May), 134-148.

Ratner, R. K., Kahn, B. E., \& Kahneman, D. (1999). Choosing less preferred experiences for the sake of variety. Journal of Consumer Research, 26, 1-15.

Reynolds, K.E., Folse, J.A.G., \& Jones, M.A. (2006). Search regret: antecedents and consequences. Journal of Retailing, 82(4), 339-348.

Richins, M.L. (1997). Measuring emotions in the consumption experience. Journal of Consumer Research, 24(September), 127-146.

Richins, M.L., \& Dawson, S. (1992). A consumer values orientation for materialism and its measurement: Scale development and validation. Journal of Consumer Research, 19(3), 303316. 
Schaefers, T., Lawson, S.J., \& Kukar-Kinney, M. (2015). How the burdens of ownership promote consumer usage of access-based services. Marketing Letters, April, 1-9.

Schwartz, B. (2004). The Paradox of choice: Why more is less. New York: HarperCollins.

Sharma, S. (1996). Applied Multivariate Techniques. New York: John Wiley \& Sons.

Shim, S., \& Gehrt, K.C. (1996). Hispanic and Native American adolescents: An exploratory study of their approach to shopping. Journal of Retailing, 72(3), 307-324.

Simonson, I. (1990). The effect of purchase quantity and timing on variety seeking behavior. Journal of Marketing Research, 27, 150-162.

Spiggle, S. (1994). Analysis and interpretation of qualitative data in consumer research. Journal of Consumer Research, 491-503.

Teo, T.S.H. (2002). Attitudes toward online shopping and the internet. Behavior \& Information Technology, 21(4), 259-271.

Trendwatching.com (2006). Transumers: Consumers driven by experiences. http://www.trendwatching.com/trends/transumers.htm. Accessed 01.12.13.

Van de Glind, P. (2013). The consumer potential of collaborative consumption: Identifying the motives of Dutch collaborative consumer and measuring the consumer potential of collaborative consumption within the municipality of Amsterdam. Unpublished master's thesis, Utrecht University, the Netherlands.

Weigel, R., \& Weigel, J. (1978). Environmental concern: The development of a measure. Environment and Behavior, 10(March), 3-15.

Zhuo, T. (2015). Airbnb and uber are just the beginning. What's next for the sharing economy. http://www.entrepreneur.com/article/244192. Accessed 28.06.15. 